\title{
HUBUNGAN PERSEPSI KINESTETIK DENGAN KETERAMPILAN SEPAK SILA PADA PERMAINAN SEPAK TAKRAW
}

\author{
Fatwa Wara Putra \\ Universitas Sembilanbelas November Kolaka, email : fatwawara13@gmail.com \\ Rahedin Suwo \\ Universitas Sembilanbelas November Kolaka, email : rahedins@usn.ac.id \\ Nasarudin \\ Universitas Sembilanbelas November Kolaka, email : nasarudin.geousn16@gmail.com
}

\begin{abstract}
Abstrak
Penelitian ini bertujuan untuk mengetahui hubungan Persepsi Kinestetik dengan Keterampilan Sepak Sila pada Permainan Sepak Takraw. Populasi dalam penelitian ini adalah siswa SMA DDI Kendari yang mengikuti kegiatan ekstrakulikuler sepak takraw sebanyak 30 orang. Sampel dalam penelitian ini menggunakan teknik (total sampling) yaitu seluruh siswa yang mengikuti kegiatan ekstrakurikuler sepak takraw di SMA DDI Kendari berjumlah 30 orang. Instrument yang digunakan adalah Tes persepsi kinestetik dengan Perception Distance Jump Test. Tes keterampilan sepak sila dengan tes penguasaan sepak sila selama 60 detik. Hasil penelitian menunjukkan bahwa terdapat hubungan antara persepsi kinestetik dengan keterampilan sepak sila pada permainan sepak takraw dengan kategori kuat, yang ditunjukkan oleh $(r 2)=60,90 \%$. Semakin baik persepsi kinestetik siswa maka semakin tinggi kemampuan sepak silanya. Kesimpulan bahwa terdapat hubungan yang erat antara persepsi kinestetik dengan keterampilan sepak sila pada permainan sepak takraw.
\end{abstract}

Kata Kunci: Persepsi Kinestetik, Kemampuan Sepak Sila

\begin{abstract}
This research aims to determine the relationship of Kinesthetic Perception with Sepak Sila abilty in the Sepak Takraw Game. The population in this research were the students of SMA DDI Kendari who participated extracurricular in the sepak takraw as many as 30 people. The sample in this research used a technique (total sampling), that all student who participated in sepak takraw extracurricular activities in SMA DDI Kendari totaled 30 people. The instrument used was the kinesthetic perception test with the Perception Distance Jump Test. The test of sepak sila ability with the 60 seconds of mastery test. The result showed that there were a relationship between kinesthetic perception with the sepak sila ability in the sepak takraw game with the strong category, which was shown by $(r 2)=60.90 \%$. The better the kinesthetic perception of students, the higher the sepak sila ability. The conclusion that there were relationship between kinesthetic perception and sepak sila ability in the sepak takraw game.
\end{abstract}

Keywords: Kinesthetic Perception, Sepak Sila Ability

\section{PENDAHULUAN}

Setiap orang saat mengerjakan hariannya maka tidak luput dari olah tubuh/ olahraga, olah rasa, dan olah pikir (Suwo, 2020). Olahraga merupakan aktivitas yang menyehatkan selain pengisi waktu luang dapat dijadikan sebagai wadah bagi atlet untuk menjadi atlet profesional dibidangnya (Suwo, 2019). Bila ditinjau dari sisi internal seorang atlet ada beberapa faktor penting yang saling 
berhubungan dengan pencapaian prestasi yang optimal dalam olahraga prestasi. Faktor-faktor tersebut adalah faktor kemampuan fisik khusus, faktor mental, penguasaan teknik serta postur tubuh yang dibutuhkan dengan cabang olahraga yang ditekuni. Seperti halnya pada cabang permainan sepak takraw merupakan salah satu cabang olahraga prestasi. Permainan sepak takraw memiliki beberapa teknik dasar yang harus dikuasai diantaranya adalah teknik sepak sila atau teknik penguasaan bola. Latihan sepak sila yaitu latihan dengan bentuk gerakan menyepak bola secara berulang-ulang pada kaki bagian dalam lebih dari sekali hingga tidak dapat dilanjutkan ulanganya (Ilham, 2018).

Untuk menampilkan permainan sepak takraw yang baik, seorang diharapkan mempunyai keunggulan dalam keterampilannya (Susana, 2013). Keunggulan tersebut dapat menunjang keberhasilan dalam melakukan setiap gerakan khususnya sepak sila pada permainan sepak takraw. Sepak sila merupakan pergerakan dasar dengan bermacam kegunaan salahsatunya untuk menahan atau menerima servis, pasing, memberi bola, dan bagi pemula digunakan pada saat servis (Setiawan, Yunitaningrum, \& Atiq, 2014).

Untuk cabang olahraga sepak takraw Sulawesi Tenggara telah banyak menciptakan atlit-atlit berbakat di olahraga sepak takraw, baik di level Nasional dan Internasional. Pada pertandingan level internasional, Sulawesi Tenggara dapat memberikan kontribusi pemain asli daerah baik putra maupun putri untuk mewakili Indonesia baik di Sea Games maupun Asian Games. Prestasi olahraga sepak takraw Sulawesi Tenggara kini telah mengalami kemunduran dengan banyaknya persaingan antar atlit dari berbagai daerah, kurang lengkapnya sarana dan prasarana olahraga sepak takraw, kurangnya pertandingan yang diadakan oleh pengurus daerah, serta kurangnya peningkatan kemampuan fisik atlit sepak takraw Sulawesi Tenggara.

Siswa SMA DDI Kendari merupakan siswa- siswa yang memiliki prestasi pada cabang olahraga sepak takraw juga sekolah tersebut sebagai salah satu sekolah yang memiliki kegiatan ekstra kurikuler pada cabang sepak takraw, serta di dukung dengan adanya sarana dan prasarana olahraga sepak takraw dalam berlatih. Sehingga peneliti tertarik untuk mengambil data tentang persepsi kinestetik dengan kemampuan sepak sila.

Penelitian in dilaksanakan untuk melihat seberapa kuat hubungan persepsi kinestetik dengan kemampuan sepak sila. Hal ini dilakukan karena belum adanya penelitian yang menjawab tentang persepsi kinestetik terhadap sepak sila. Beberapa penelitian lain mengatakan apabila seorang pemanah memiliki persepsi kinestetik untuk berprestasi yang baik, pastinya seorang atlet dapat berprestasi secara maksimal (Akbar, 2018). Senada dengan itu adanya interaksi yang signifikan antara persepsi kinestetik terhadap hasil groundstrokes tenis lapangan (Suryono, 2016). Terdapat hubungan positif secara bersamasama antara konsentrasi dan persepsi kinestetik terhadap kemampuan shooting pada pemain U-11 tahun Ragunan Soccer School (Hutabarat, Watimena, \& Fitranto, 2017).

Untuk meningkatkan kualitas koordinasi gerak sebagai cerminan dari persepsi kinestetik, pelatih harus mampu membuat program dan latihan-latihan meningkatkan kemampuan persepsi kinestetik untuk para pemain sepak takraw supaya memiliki kepekaan terhadap gerakan yang dilakukan sehingga memberikan kontribusi terhadap penampilannya saat melakukan sepak sila.

Penelitian relevan berikut ini mengungkapkan terdapat hubungan yang signifikan antara koordinasi mata-kaki 
terhadap kemampuan sepak sila (Nusufi, 2014). Senada dengan itu, penggunaan media pembelajaran dengan bola plastik dapat diterapkan untuk pembelajaran sepak sila (Setiawan \& dkk, 2014). Penggunaan media pelatihan bola modifikasi ini ternyata dapat memberikan peningkatan hasil prestasi sepak sila (Susana, 2013). Penelitian berikut juga mengungkapkan adanya peningkatan kemampuan sepak sila melalui media bola karet (Rauf, 2020). Lebih lanjut adanya korelasi yang erat antara keseimbangan dan kelincahan dengan keterampilan Sepak Sila (Zulman, Umar \& Atradinal, 2018). Berdasarkan penelitian sejenis dan relevan di atas, peneliti menemukan permasalahan yang belum terjawab dan harus dibuktikan tentang keterkaitan antara persepsi kinestetik dengan kemampuan sepak sila. Sehingga, penelitian ini memiliki urgensi. Seperti yang diungkapkan oleh penelitian berikut tidak ada interaksi antara metode latihan (resiprokal dan inklusi) dan persepsi kinestetik terhadap keterampilan teknik overhead lob forehand pada bulu tangkis (Tamim, 2017). Penelitian lain mengungkapkan tidak terdapat hubungan yang signifikan persesi kinestetik terhadap akurasi tembakan jarak 50 meter (Baskoro, 2016). Sehingga hal ini mendorong peneliti untuk mengetahui dan membuktikan keterkaitan antara persepsi kinestetik dengan kemampuan sepak sila permainan sepak takraw.

Memperhatikan kelemahan dan keunggulan berbagai faktor, penelitian ini dimaksudkan untuk mengetahui seberapa erat sumbangsi persepsi kinestetik dengan kemampuan sepak sila permainan sepak takraw siswa putra ekstrakurikuler SMA DDI Kendari.

\section{METODE}

Merujuk pada judul dan tujuan di atas, maka metode penelitian yang terapkan dalam penelitian ini adalah menggunakan penelitian deskriptif dengan metode korelasional. Penelitian ini akan mendeskripsikan keterkaitan antara persepsi kinestetik dengan kemampuan sepak sila pada permainan sepak takraw. sampel penelitian adalah seluruh siswa yang mengikuti ekstrakulikuler sepak takraw yang berjumlah 30 orang. Teknik pengambilan sampel menggunakan teknik Total Sampling yaitu Siswa kegiatan ekstrakurikuler yang keseleruhannya berjenis kelamin pria.

Instrumen yang digunakan untuk mengukur Persepsi Kinestetik dilakukan dengan Perception Distance Jump Test dan instrumen yang digunakan untuk mengukur keterampilan sepak sila dilakukan dengan tes penguasaan sepak sila.

\section{HASIL DAN PEMBAHASAN}

Hasil

Instrumen yang diterapkan pada penelitian ini untuk mengukur kemampuan sepak sila yaitu tes penguasaan sepak sila. Hasil dari uji data dapat dilihat pada tabel berikut:

Tabel 1. Distribusi frekuensi keterampilan sepak sila

\begin{tabular}{c|c|c|c}
\hline \multirow{2}{*}{ Kelas Interval } & $\begin{array}{c}\text { Frekuensi } \\
\text { Absolut }\end{array}$ & $\begin{array}{c}\text { Frekuensi } \\
\text { Kumulatif }\end{array}$ & $\begin{array}{c}\text { Frekuensi } \\
\text { Relatif }\end{array}$ \\
\cline { 2 - 4 } & (f) & (f.k) & (\%) \\
\hline $20,00-24,20$ & 4 & 4 & 13,33 \\
\hline $24,21-28,41$ & 5 & 9 & 16,67 \\
\hline $28,42-32,62$ & 5 & 14 & 16,67 \\
\hline $32,63-36,83$ & 4 & 18 & 13,33 \\
\hline $16,84-41,04$ & 7 & 25 & 23,33 \\
\hline $41,05-45,25$ & 5 & 30 & 16,67 \\
\hline Jumlah & 30 & & 100,00 \\
\hline
\end{tabular}

Berdasarkan distribusi frekuensi pada Tabel 1 di atas, diperoleh gambaran bahwa sebanyak 14 orang $(46,67 \%)$ memiliki keterampilan sepak sila di bawah kelompok rata-rata, sebanyak 4 orang $(13,33 \%)$ memiliki keterampilan sepak sila 
pada kelompok rata-rata, dan sebanyak 12 orang $(40,00 \%)$ memiliki keterampilan sepak sila di atas kelompok rata-rata.

Instrumen yang diterapkan pada penelitian ini untuk mengukur persepsi kinestetik yaitu tes penguasaan sepak sila. Hasil dari uji data dapat dilihat pada tabel berikut:

Tabel 2. Distribusi Frekuensi Persepsi Kinestetik

\begin{tabular}{c|c|c|c}
\hline \multirow{2}{*}{$\begin{array}{c}\text { Kelas } \\
\text { Interval }\end{array}$} & $\begin{array}{c}\text { Frekuensi } \\
\text { Absolut }\end{array}$ & $\begin{array}{c}\text { Frekuensi } \\
\text { Kumulatif }\end{array}$ & $\begin{array}{c}\text { Frekuensi } \\
\text { Relatif }\end{array}$ \\
\cline { 2 - 4 } & (f) & (f.k) & (\%) \\
\hline 93 & 4 & 4 & 13,33 \\
\hline 94 & 5 & 9 & 16,67 \\
\hline 95 & 5 & 14 & 16,67 \\
\hline 96 & 4 & 18 & 13,33 \\
\hline 97 & 6 & 24 & 20,00 \\
\hline 98 & 5 & 29 & 16,67 \\
\hline 99 & 1 & 30 & 3,33 \\
\hline Jumlah & 30 & & 100.00 \\
\hline
\end{tabular}

Apabila persepsi kinestetik dibuat dalam bentuk distribusi frekuensi, diperoleh sebanyak 4 orang (13,33\%) memiliki persepsi kinestetik dengan skor 93, sebanyak 5 orang $(16,67 \%)$ memiliki persepsi kinestetik dengan skor 94, sebanyak 5 orang $(16,67 \%)$ memiliki persepsi kinestetik dengan skor 95, sebanyak 4 orang $(13,33 \%)$ memiliki persepsi kinestetik dengan skor 96, sebanyak 6 orang $(20,00 \%)$ memiliki persepsi kinestetik dengan skor 97, sebanyak 5 orang $(16,67 \%)$ memiliki persepsi kinestetik dengan skor 98, sebanyak 1 orang $(3,33 \%)$ memiliki persepsi kinestetik dengan skor 99.

\section{Pembahasan}

Pada penelitian terdahulu telah menjelaskan dan menjawab berbagai masalah pada permainan sepak takraw. Namun, peneliti menemukan masalah yang belum terjawab oleh penelitian lain. Sehingga penelitian ini telah dilaksanakan untuk menuntaskan permasalahan yang ada pada permainan sepak takraw khususnya korelasi antara persepsi kinestetik dengan kemampuan sepak sila siswa putra ekstrakurikuler SMA DDI Kendari.

Berdasarkan hasil uji statistik antara persepsi kinestetik dengan kemampuan sepak sila memperlihatkan hubungan yang kuat. Sejalan dengan itu, persepsi kinestetik memiliki kontribusi yang signifikan terhadap atlet Panahan Kota Palopo (Akbar, 2018). Ada hubungan secara signifikan antara persepsi kinestetik dan kemampuan handspring pada meja lompat (Ferawati, 2018). Hal ini menandakan bahwa semakin tinggi persepsi kinestetiknya maka semakin baik pula kemampuan sepak silanya.

Korelasi antara persepsi kinestetik dengan kemampuan sepak sila sepak takraw siswa putra ekstrakurikuler SMA DDI Kendari dipastikan memiliki hubungan yang kuatberdasarkan nilai $(r 2)=60,90 \%$. Dengan demikian, jika seseorang memiliki persepsi kinestetik yang baik maka maka kemampuan sepak sila akan baik. Begitupun sebaliknya, jika seseorang memiliki persepsi kinestetik rendah maka kemampuan sepak sila akan rendah. Ada interaksi yang signifikan antara metode latihan dan persepsi kinestetik terhadap hasil groundstrokes tenis lapangan (Suryono, 2016). Selanjutnya memiliki kontribusi rendah antara persepsi kinesteti terhadap ketepatan shooting petanque (Prad, 2019).

Berdasarkan hasil-hasil dan temuan yang diperoleh dalam penelitian ini menunjukkan bahwa secara keseluruhan hipotesis penelitian dapat dibuktikan melalui data empiris, dimana persepsi kinestetik yang dikaji mempunyai hubungan yang erat dengan variabel keterampilan sepak sila pada permainan sepak takraw siswa putra ekstrakurikuler SMA DDI Kendari. 


\section{PENUTUP}

\section{Simpulan}

Persepsi kinestetik memiliki korelasi yang erat dengan kemampuan sepak sila permainan sepak takraw siswa putra ekstrakurikuler SMA DDI Kendari. Dengan memiliki persepsi kinestetik yang baik maka kemampuan menyepak bola akan baik pula.

\section{Saran}

Hasil penelitian ini sebagai tambahan wawasan bagi pelatih sepak takraw siswa putra ekstrakurikuler SMA DDI Kendari dalam penyusunan program latihan.

\section{DAFTAR PUSTAKA}

Akbar, A. K. (2018). Analisis Persepsi Kinestetik Terhadap Kemampuan Memanah Atlet Panahan Kota Palopo. Jurnal Penjaskesrek STKIP Mega Rezky Makassar, 4(2), 115$127 . \quad$ Retrieved from http://ejournal.stkipmegarezky.ac.id/ index.php/Penjaskesrek/article/dow nload/97/69

Baskoro, D. A. (2016). Hubungan Kekuatan Otot Lengan, Vo2 Max dan Persepsi Kinestetik Terhadap Akurasi Tembakan Jarak 50 Meter. ACTIVE: Journal of Physical Education, Sport, Health and Recreation, 5(3), 130-133. Retrieved from https://journal.unnes.ac.id/sju/index .php/peshr/article/download/11605/ 7123

Ferawati, F. (2018). Pengaruh Persepsi Kinestetik Terhadap Kemampuan Handspring On Vault Atlet Persani Sulawesi Selatan. Jurnal Penjaskesrek STKIP Mega Rezky Makassar, 3(2), 90-98. Retrieved from http://ejournal.stkipmegarezky.ac.id/ index.php/Penjaskesrek/article/dow nload/63/42

Hutabarat, A. L., Watimena, F. Y., \& Fitranto, N. (2017). Hubungan
Konsentrasi dan Persepsi Kinestetik Terhadap Kemampuan Shooting Pada Pemain U-11 Tahun Ragunan Soccer School. Jurnal IImiah Sport Coaching and Education, 1(2), 78-92. Retrieved from http://journal.unj.ac.id/unj/index.ph p/jsce/article/download/4481/3397

Ilham, I. (2018). Pengaruh Latihan Sepak Sila Dan Sepak Kuda Terhadap Kemampuan Servis Sepak Takraw. Cendekia: Jurnal Pendidikan Dan Pengajaran, 1(2), 365-375. Retrieved from

https://www.ojs2.ikippgrikaltim.ac.id /index.php/Cendekia/article/view/29 $/ 25$

Nusufi, M. (2014). Korelasi Antara Koordinasi Mata-Kaki dengan Kemampuan Sepak Sila Dalam Permainan Sepak Takraw Atlet Klub Dondong Merah Tahun 2014. Jurnal Handayani PGSD FIP UNIMED, 6(2), 1-8. Retrieved from https://jurnal.unimed.ac.id/2012/ind ex.php/handayani/article/viewFile/6 515/9514

Pernandes, A., \& Sutisyana, A. (2018). Pengaruh Latihan Bola Gantung Terhadap Kemampuan Smash Kedeng Dan Smash Gulung Dalam Permainan Sepak Takraw Pada Atlet Psti Kabupaten Lebong. Kinestetik, 2(1), 89-96.

Rauf, A. (2020). Upaya Meningkatkan Hasil Belajar Sepak Sila Melalui Media Bola Karet dalam Permainan Sepaktakraw pada Siswa SMA Negeri 7 Kab. Pangkep. (Doctoral Dissertation, UNIVERSITAS NEGERI MAKASSAR). Retrieved from http://eprints.unm.ac.id/17232/

Saputra, H. A., Yarmani, Y., Sugihartono, T., \& Defliyanto, D. (2018). Penerapan 
Variasi Modifikasi Bola Karet Untuk Meningkatkan Keterampilan Servis Bawah Sepak Takraw. Kinestetik, 2(2), 215-225. https://doi.org/10.33369/jk.v2i2.874 4

Setiawan, D., Yunitaningrum, W., \& Atiq, A. (2014). Pengaruh Media Bola Plastik Terhadap Teknik Dasar Sepak Sila di Sekolah Menengah Atas. Jurnal Pendidikan Dan Pembelajaran Khatulistiwa, 4(2). Retrieved from http://jurnal.untan.ac.id/index.php/j pdpb/article/download/9035/pdf

Sucipto, B., \& Sugiyanto, S. (2017). Upaya Meningkatkan Kemampuan Sepak Sila Melalui Variasi Latihan Berpasangan Pada Permainan Sepak Takraw Siswa Kelas V Sd Negeri 18 Kota Bengkulu. Kinestetik, 1(1).

Suryono, S. (2016). Pengaruh metode latihan dan persepsi kinestetik terhadap keterampilan groundstrokes tenis lapangan pada siswa SD. Jurnal Keolahragaan, 4(2), 220-231. Retrieved from https://journal.uny.ac.id/index.php/j olahraga/article/download/10901/85 31

Susana, A. (2013). Penggunaan media pelatihan bola modifikasi terhadap hasil prestasi sepak sila pada ekstrakurikuler sepak takraw (studi pada peserta ekstrakurikuler smp negeri 3 srengat kabupaten blitar). Jurnal Pendidikan Olahraga Dan Kesehatan, 1(1). Retrieved from https://jurnalmahasiswa.unesa.ac.id/ index.php/jurnal-pendidikanjasmani/article/viewFile/2816/5729

Suwo, R. (2019). Pengaruh Kecepatan Reaksi Tangan, Terhadap Kemampuan Forehand Topspin (Path Analysis Pada Atlet Tenis Meja UNSIKA Karawang 2016). Riyadhoh:
Jurnal Pendidikan Olahraga, 1(1), 21$25 . \quad$ Retrieved from https://ojs.uniskabjm.ac.id/index.php/riyadhohjurnal/ article/download/1703/1348

(2020). Correlation Between Agility and Athletes Topspin of Table Tennis in Kendari City. JUARA: Jurnal Olahraga, 5(1), 55-65. Retrieved from

http://jurnal.upmk.ac.id/index.php/j uara/article/download/770/450

Tamim, M. H. (2017). Pengaruh metode latihan (resiprokal dan inklusi) persepsi kinestetik terhadap teknik overhead lob forehand bulu tangkis. Jurnal Keolahragaan, 5(1), 71-80. Retrieved from https://journal.uny.ac.id/index.php/j olahraga/article/download/12806/93 82

Warta Kusuma Cucu Prad, S. Y. A. H. R. U. D. I. N. (2019). Kontribusi Tinggi Badan, Panjang Lengan, Keseimbangan, Konsentrasi Dan Persepsi Kinestetik Terhadap Ketepatan Shooting Pada Olahraga Petanque. Jurnal Prestasi Olahraga, 1(1). Retrieved from https://jurnalmahasiswa.unesa.ac.id/ index.php/jurnal-prestasiolahraga/article/download/26919/24 636

Zulman, F. U., Umar, A., \& Atradinal, F. U. (2018). Hubungan Keseimbangan dan Kelincahan terhadap Keterampilan Sepak Sila Pemain Sepaktakraw SMP Negeri 2 Batang Anai. Jurnal Menssana, 3(1), 77-88. Retrieved from http://menssana.ppj.unp.ac.id/index. php/jm/article/download/68/55 